\title{
The Influence of Absorption Graduates Vocational Education: A Case Study
}

\author{
Tuty Sariwulan ${ }^{1}$ \\ Widodo $^{2}$ \\ Novrian Satria Perdana ${ }^{2}$ \\ Fajarini $^{2}$ \\ Iskandar Agung ${ }^{2}$ \\ ${ }^{1}$ Faculty of Economy, State University of Jakarta, \\ Jakarta, Indonesia \\ ${ }^{2}$ Center for Research Policy of Education and Culture, \\ Research and Development Agency, MOEC, Indonesia
}

Doi: 10.36941/ajis-2020-0o23

Abstract

This study aims to determine the factors that influence employment absorption of vocational high school (SMK) graduates. This research is a case study in three Vocational Schools with a sample of 120 people from 11-12th grade students. Data collection was carried out using a questionnaire and analyzed with the help of the Lisrel 8.80 program. This study found that the School Management (SM) and Industrial Environment (IE) variables had a positive effect on the Teaching Factory (TF) variable. Furthermore, all three variables (SM, IE, and TF) have a positive effect on the absorption variable of vocational high school graduates (ALV). Even the SM and IE variables have a greater positive effect than TF on the ALV variable. This means that the Tefa (TF) program still does not support graduates in getting jobs, especially because it is more directed towards low skills and unable to meet DUDI needs for middle and highs level competencies. It is recommended that the government needs to authorize schools to develop education in accordance with environmental condition potential, increase cooperation between schools - local governments - DUDI, enhance Tefa learning which refers to developing secondary and high skills to meet competencies according to the needs of the world of work by developing curricula and work practices together.

Keywords: government policy, employment needs, environmental conditions, school management, industrial environment, work absorption

\section{Introduction}

Republic of Indonesia Government Regulation No. 66 of 2010 confirms that vocational education (SMK) is one of the levels of secondary education with the specificity of preparing graduates ready for work. One of the ways implemented since 10 years ago is the application of the Teaching Factory (Tefa) model for various types of vocational education, such as: vocational tourism, hospitality, automotive, graphics, and others. Tefa is a production / service based learning model that refers to standards and procedures that apply in the industry. The Tefa model in schools is based on learning 
activities according to reality by involving the industrial sector in developing student competencies. The aim is to transfer the production environment in the industry into the school, so that graduates are ready to work and can be absorbed in industrial companies (Directorate of PSMK, 2015, 2017a,b; 2018a,b).

Data the Central Bureau of Statistics in 2016 noted that 189.10 million people were of working age, but only 118.41 million were categorized as workers in various sectors. From the data on the number of employed people, more than half are those who work with low educational backgrounds who fill job opportunities that are less demanding for specific skills. The challenge that still needs to be done is how to improve the educational background of Indonesian workers, at least secondary education. But the effort was not easy, because the implementation of secondary education also only produced and increased the number of unemployed, especially vocational education graduates (SMK). Data the Central Statistics Agency in 2017 noted that the number of workers in Indonesia in February 2018 was 133.94 million people, of which 6.87 million people were categorized as unemployed. From the data available, the highest unemployment rate is SMK graduates who reached 11.24 percent in August 2018 (see: Andreas, 2018). The cause of the high unemployment rate for SMK graduates is oversupply, in addition to the incompatibility of certain SMK graduates with existing industry needs and the quality of graduates who do not meet industry standards (Directorate of PSMK, 2010). Especially the latter mentioned through the implementation of the Tefa program is expected to be able to prepare the competence of students and graduates of vocational schools absorbed by vocational schools in the world of work (industrial and service companies).

Why is Tefa's implementation still unsatisfactory demonstrated by its graduates who are not absorbed in the job opportunities available? Each year there is an increase in the number of unemployed SME graduates, increasing the number of unemployed. It is suspected that the implementation of the Tefa program is not well planned and is top-down so schools do not have the freedom to develop their own programs. While school education not only cares about the environment, but also the existence and type of DUDI around it.

Based on this, this paper wants to know the factors that influence the absorption of the vocational workforce of the SMK graduates. These influencing factors are school management (SM), environmental industry (IE), and teaching factory (TF) programs. All three are thought to be influenced by complex factors, including government Policy (GP), employment needs (EN), and environmental conditions (EC). GP, EN, and EC factors are exogenous latent variables that influence the latent variables of SM, IE, and TF. Furthermore, SM, IE, and TF are exogenous latent variables that influence the latent variable of endogenous SMK (ALV) worker absorption.

\section{Literatur Review}

Understanding needs to be expressed in this paper is the government's policy, labor needs, environmental conditions, SMK management, business / industry participation, and teaching factory.

\subsection{Government Policy (GP)}

In Indonesian Regulation No. 29 of 1990 article 29 paragraph (2) mentioned Secondary Education to prepare vocational students to become professional production workers. Production is a school-based education and training program to optimize the resources available to provide greater value. For this reason, the government has provided assistance in providing learning facilities and practical facilities by bringing the industry to school, so that students can do their activities according to reality (Directorate of Vocational Schools, 2017a). In 2011 the government implemented a Tefa program based on production / service oriented learning that focused on industry standards and procedures and implemented in an industry-like setting. Tefa's basic conception rests on the relocation of the industrial production environment to the classroom practice room. The implementation of this learning model fully integrates learning and work, no longer separating the delivery of theory and 
practice (Vocational School Directorate, 2015).

The government is committed to implementing the Tefa model in SMK with financial assistance, provision of study facilities, instructors and more. Tefa organizers receive funding in the hope of creating a balance and alignment between the competencies of the vocational School graduates and the needs of the business / industry world (often referred to as: DUDI), enhancing collaboration between the Vocational and DUDI schools, enhancing students' ability to produce product / service products in accordance with market standards, and the development of supply / demand / supply / supply mechanisms (Vocational School Directorate, 2018a; 2018b). Wijaya (2013) points out that schools that are the object of their research receive financial assistance, instructor training, and more so that students can achieve certain competencies.

\subsection{Employment Needs (EN)}

There is an assumption that the unemployment phenomenon for vocational graduates is due to lower demand than the supply. That may be true, but on the other hand, there are still many job opportunities that can be taken advantage of by junior high school graduates. Perdana (2019) points out that, although there is a larger supply of vocational graduates compared to their demand, there are still many job opportunities that graduate graduates can fill. The need for DUDI for a competent workforce cannot be met by the supply of vocational school graduates. Vocational education, which is considered to have a strategic role in fulfilling the secondary workforce, is far from industry standard. Qualified and certified workforce is hard to find in most industries, because link \& match programs don't work as expected.

Whereas the demand for the medium skilled labor is increasing. The Ministry of Industry of the Republic of Indonesia estimates that labor demand in the industrial sector will increase by more than $8 \%$ by 2035 . The increase is spread across all manufacturing sub-sectors, such as food and beverage, metal, textiles, apparel, and the automotive industry. High labor demand coincides with the influx of investment in Indonesia and government efforts to intensify the industrial sector, growing both in domestic and export markets (Okezone, 2019). The Ministry of Economic Cooperation of the Republic of Indonesia (2017) notes that between 2017 - 2025 it will require at least 1.3 million workers ranging from natural goods processing, basic commodities, information technology, health, financial services, infrastructure, transportation, to energy and telecommunications services. However, meeting these needs is not just a matter of quantity but the quality of human resources according to the needs of the industrial world. Handayani (2015) proposed a strategic step for the government to undertake a more extensive vocational education and training activity, in order to avoid the emergence of a shortage of educated and skilled workers but the disadvantages of unskilled workers. The Ministry of Labor's Planning and Development Agency processed from CBS data in 2015 shows that the number of skilled workers requires 3.7 million skilled workers per year. According to research by the McKinsley Global Institute (MGI) Indonesia's skilled workforce needs to reach 113 million by 2030 (News Detik, 2017).

Field studies of labor demand in a number of sectors are conducted by various parties. For example, Husen's (2000) study concluded that employment in tourism has good prospects, but it requires effort to improve the knowledge and skills of the workforce in this sector. Traymansah, Soejitno, and Personal (2012) found a shortage of skilled workers in the shipping industry. Or Sumantri et al (2016) show that the maritime industry in Indonesia desperately needs skilled labor for workers on commercial ships, yachts, etc.

\subsection{Environmental Conditions (EC)}

In line with the implementation of regional autonomy, education development applies the principle of decentralization by giving schools greater authority to manage all aspects of their educational institutions, or known principles of School Based Management (SBM). Through decentralized 
education it is hoped that schools will be able to build partnerships with local governments and DUDI and exploit the potential for excellence in their areas through the application of vocational education. According to Wagiran (2010) factors that can integrate vocational education programs with the regional economy are labor productivity. Vocational education must support the mission of preparing graduates with the skills and abilities to become productive workers. Meanwhile, the district and DUDI are trying to get the vocational graduates needed to develop and utilize the economic potential of the region.

Indriaturrahmi and Sudiyatno (2016) and Asmani (2012) have suggested that local wisdom needs to be developed based on regional potential by coordinating between DUDI, local government, and vocational schools. The coordination program is intended to tailor graduate supply to the workforce needs represented by the job level. Djojonegoro (1998) states that vocational education will be effective if one of them is in keeping with the environment in which students are trained so that they are replicas of the environment in which they work. The orientation of vocational education should always be close to the potential of the surrounding environment, and supported by collaboration with the business / industry world as beneficiaries of the environment and providers of vocational school graduates. It is stated by the Directorate of Vocational Education (2017), that successful management of the environment must be supported by the highest quality human resources available through education in accordance with the competencies required to develop regional winning potential. This competency is further into the realm of vocational education leading to skills at the intermediate level.

Various studies have shown the importance of considering the potential of the environment in the provision of vocational education. Dardiri (2015) found that the potential utilization of the environment led to collaboration between schools and DUDI so as to enhance the quality of graduates, strengths and image of the school. Wati (2018) shows that learning based on local potential utilization in vocational education has produced products for the development of small businesses around it. Rukmawan (2017) argues that the industrial environment makes the position of SMKN 1 Karawang - the province of West Java very strategic in working with DUDI, so that schools can develop expertise packages to meet the needs of DUDI not only locally but also in other countries. However, studies conducted by various parties have often shown that local government, DUDI, and education in vocational schools have yet to capitalize on the potential of the environment. Indriaturrahmi and Sudiyatno (2016) for example show that DUDI and the Government of the Mataram City District, West Nusa Tenggara Province - Indonesia, have not yet pushed education in vocational schools based on environmental potential. Irfan, Nurlaila, and Sunardi (without a year) state that graduates tend to misrepresent their vocational vocational schools because they are irrelevant to the competencies they possess with the potential of excelling in the area. Aini, Sulistyarso and Purwadio (without years) argued that although a number of companies developed small and medium-sized businesses, graduates were less absorbed in the industry because of their low skills.

\subsection{School Management (SM)}

Management is simply defined as the utilization of resources (human and non-human) through the process of planning, organizing, implementing, and monitoring, to achieve certain goals (see: Terry, 2010; Priyono, 2016). School as an organization requires systematic planned management to influence, mobilize, and direct the behavior of members in it to achieve the expected goals. Organizational management will achieve maximum results and achievement, if individuals and groups will realize activities in accordance with the objectives and expected results (Manullang 2013; Stoner, 2013).

The importance of school management elements has been realized by the government with the issuance of the school-based management concept / MBS (Law No. 20 of 2003) by giving schools 
greater authority and flexibility in managing all aspects of education in their institution to lead to school improvement. Specifically for Vocational Schools, education management is considered to be relatively more complex than conventional schools because it is associated with producing workforce that requires cooperation with outside parties (government, DUDI, etc.) through the concept of links \& competition (Cahyanti et al , 2018; Disas, 2018). In the context of implementing the Tefa program, school management should focus on student mastery and skills in industry activities, accuracy, size, and comprehensiveness. Tefa learning process means process-based education and training to achieve certain capabilities. For this reason schools are accompanied by clear and rigid legal aspects for the implementation of Tefa (Vocational Education Directorate, 2017b).

Nurdin study (2011) showed that the school management in the development of a good program will generate Tefa vision and mission and goals of the school is effective and efficient. Rahardjo and Yuliana (2016) suggest that school management goals, including the availability of educational facilities, learning activities, and competent teacher support, can lead to effective school goals. Purnanto and Imron (2012) suggest that school management that promotes collaborative networks with DUDI can have a positive impact on schools and DUDI, especially in the form of graduate absorption. But a number of studies also indicate that there are still barriers to TEFA implementation, including the absence of school specialists to handle programs, incomplete learning infrastructure, inadequate instructors, school-district cooperation - DUDI - local governments, and many DUDI note of agreement.

\subsection{DUDI Participation}

In Indonesia, the regulation states that the implementation of education is the responsibility of the government, the community, and parents of students (Law of the Republic of Indonesia Number 20 of 2003). Implicitly, the implementation of education is not only a matter of governance, but requires active participation from the community and parents of students. Participation can be defined as the involvement of a person or group of people to strive for the success of an activity, so as to achieve the expected goals. Davis and Newstrom (2004) argue that participation is the mental and emotional involvement of a person to achieve goals and take responsibility in them. Participation is the mental and emotional involvement of someone who is motivated to contribute and achieve group goals. There are at least 4 (four) forms of participation in schools, namely: financial participation, property participation (for example: personal computer assistance, laptops, props, wifi provisioning, etc.), participation in physical services (for example: building classrooms, maintaining security school environment, etc.), and participation in skills (for example: as a resource, looking for experts to provide guidance, and so on).

Especially in the implementation of education in vocational schools, the form of community participation has different characteristics from conventional schools. DUDI as one component of the community is expected to be able to realize active participation in vocational education, known as the concept of link and match. This concept in the implementation of education in Indonesia refers to the relevance and appropriateness of education in vocational schools with the needs of DUDI (Djojonegoro, 1999; Judissuseno, 2008: 14). Through link and match can form the competence of vocational graduates who are acceptable and match the needs of the workforce. One learning model used as a link and match policy strategy is the application of Tefa. Tefa learning model based on real experience in the industrial world is expected that vocational graduates can be absorbed in the world of work. Strictly DUDI participation is not limited to only providing financial assistance, equipment, and so on, but also fostering cooperation with vocational schools in providing student practice, providing professional instructors to provide training in companies and schools, providing learning facilities, preparing curriculum in accordance with competencies what students need, and so on.

One of them is Rukmawan (2017), as the Principal of a Vocational School the educational institution he leads is surrounded by various types of businesses / industries so he feels fortunate to be able to collaborate and organize education that is adaptive to their needs. The positive impact 
obtained by schools is that almost all graduates can be absorbed as workers in these companies. Santosa (2018), Kuswantoro et al (2012), Handayani et al (2018) showed DUDI participation in the implementation of the Tefa program in Vocational Schools succeeded in increasing student competency, providing Tefa learning facilities and quality and creative product results to be marketed to consumers. Siswanto (2015) argues, the successful implementation of Tefa in vocational automotive engineering expertise programs is strongly influenced by the support of industry in terms of facilities and infrastructure.

\subsection{Teaching Factory}

Tefa implementation is an effort to empower vocational schools to develop cooperation with DUDI and various other relevant institutions. Tefa is the concept of learning in actual situations to increase the relevance of vocational education to the needs of the world of work by strengthening the academic skills of vocational students, increasing the readiness of secondary education students to enter the job market, encouraging industries to provide apprenticeship facilities, and developing a curriculum that is aligned with job needs based on input from the business / industry world (Directorate of Vocational Education, 2015; Haris, 2013).

Various studies indeed show that the application of the Tefa program is quite effective in producing vocational graduates who are absorbed as workers (Yunanto, 2016; Sari, 2017; Perdana, 2018), the Mustari et al (2017) study states, based on the results of the analysis with N Gain it is known that the model Tefa learning is effective for improving vocational skills. Zainudin (2012) shows that the application of Tefa contributes to the improvement of students' knowledge, abilities, experience, discipline, and professional attitudes that are useful in entering the workforce. But on the other hand the application of Tefa often still shows obstacles, including teachers who lack training from the government so that they are less competent, learning still uses the teacher centered method or assignments to be completed which makes students experience boredom, boredom, and less creative, Tefa learning that has not produced graduate skills, limited technical management / implementing staff and equipment limitations, and others (Fajaryati, 2012; Anwar and Wailanduw, 2018; Yunanto, 2016; Mustari et al, 2017; Supraptono, 2017; Arifman, 2017; Prime, 2018).

\subsection{Theoretical Framework}

Based on the description above, a theoretical framework is proposed to study the problem, as shown in diagram 1.

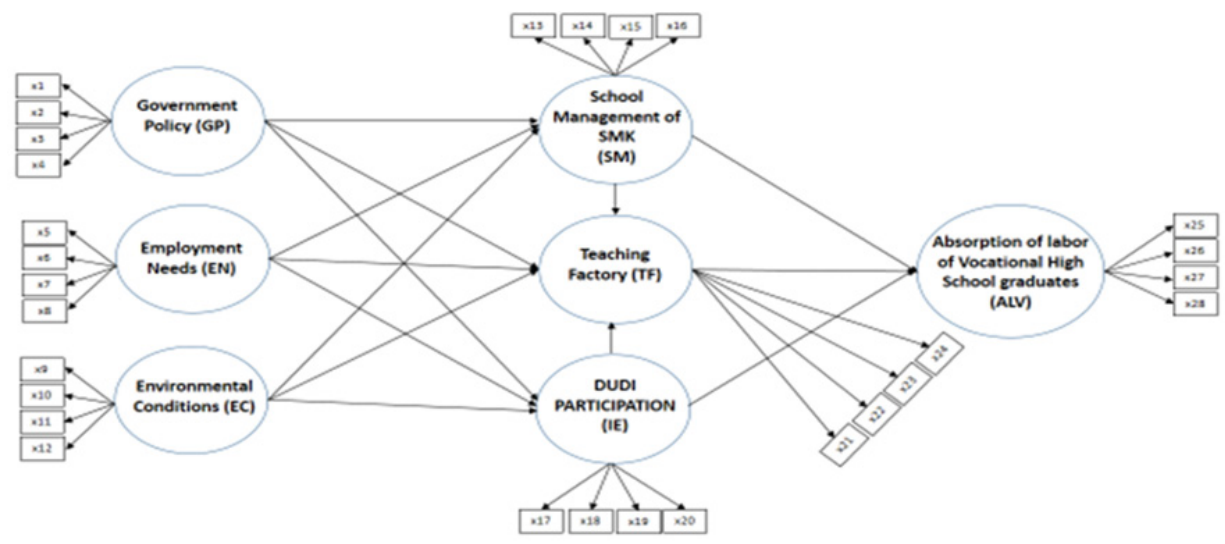

Diagram 1: Influence factors on Absorption of Workers in SMK Graduates: Case Stuy, 2019 
The hypothesis is proposed as follows.

- Variables Government Policy (GP), Employment Needs (EN), and Environmental Potential (EP) have the influence of School Management (SM), DUDI Participation (IE), and Teaching Factory (TF) variables.

- Variables School Management (SM), DUDI Participation (IE), and Teaching Factory (TF) have an influence on the variable Absortion of Labor of Vocational High School Graduates (ALV).

\section{Methodology}

The study was conducted in June 2019 at three state secondary schools (SMK) in the city of East Jakarta - DKI Jakarta Province, Karawang District - West Java Province, and Malang - East Java Province. The research sample consists of students in grades 11-12 of the Metal Fabrication and Manufacturing Engineering study program, Automotive Engineering, Electronics Industry Engineering, and Hospitality. A total of 120 samples were obtained by random sampling technique, consisting of 30 students in each department.

\subsection{Collecting data and information technique}

Data collection was carried out through the distribution of questionnaires to students and was supported by interviews and focus group discussions with school principals, teacher / instructor learning factories, and DUDI entrepreneurs. Specifically, the questionnaire before being implemented was tested using Pearson and Alpha Cronbach correlation coefficient criteria which were processed using the SPSS program version 24.0. The minimum validity criterion for the validity test is $=0.361$, and the reliability test is $\geq 0.6$. Questions in the invalid and unreliable questionnaire were not used, and only questions that proved to be valid and reliable were used in subsequent fieldwork.

\subsection{Analysis data technique}

The analysis used structural equation modelling (SEM) using the Lisrel 8.80 program. SEM can be used because the number of samples meets the minimum requirement of 100 respondents (Kusnendi, 2009; Haryono and Wardoyo, 2013).

\section{Results}

\subsection{Characteristic Respondent}

From the field, $76(63.33 \%)$ of the respondents in grade 11 gave the answer to the questionnaire and 44 (36.67\%) of the respondents in class 12 . Of the $88(73.33 \%)$ respondents were male and $32(26,67) \%$ are female students. The number of male college students is higher than that of women. There is a similarity in the main reason for men and women who are studying for a high school education, who want to work quickly after graduation. On the other hand, most of the vocational students surveyed come from parents with lower socioeconomic status, so they immediately want to help their families. The educational situation of a vocational student is generally different from that of a public high school student who prefers to pursue higher education (university).

\subsection{CFA Results \\ 4.2.1 Validity test results}

Latan (2012) suggests that a confirmatory factor analysis (CFA) be conducted to test the 
dimensionality of a construct or variable. CFA must be implemented as a test of validity and reliability to determine whether indicator variables truly form the latent variables studied (Haryono and Wardoyo. 2017). The validity test is performed to determine whether the question items meet the standardization value of the factor. If the value of the standard loading factor is greater than 0.5. the question item is valid. The CFA test results in the table 2 show that all statements or indicators in this study are valid, because they have a loading value greater than 0.5 .

Table 1. CFA Validity Results

\begin{tabular}{|c|c|c|c|}
\hline Variables & Indicators & loading factor & Conclusion \\
\hline \multirow{4}{*}{ Government Policy (GP) } & $\mathrm{X}_{1}$ & 0,83 & Valid \\
\hline & $\mathrm{X}_{2}$ & 0,79 & Valid \\
\hline & $\mathrm{X}_{3}$ & 0,98 & Valid \\
\hline & $\mathrm{X}_{4}$ & 0,98 & Valid \\
\hline \multirow{4}{*}{ Employment Needs (EN) } & $\mathrm{X}_{5}$ & 0,89 & Valid \\
\hline & $\mathrm{X} 6$ & 0,87 & Valid \\
\hline & $\mathrm{X}_{7}$ & 0,88 & Valid \\
\hline & $\mathrm{X} 8$ & 0,98 & Valid \\
\hline \multirow{4}{*}{ Environmental Condition (EC) } & $\mathrm{X}_{9}$ & 0,89 & Valid \\
\hline & $\mathrm{X}_{10}$ & 0,96 & Valid \\
\hline & $\mathrm{X} 11$ & 0,85 & Valid \\
\hline & $\mathrm{X}_{12}$ & 0,99 & Valid \\
\hline \multirow{4}{*}{ School Management of SMK (SM) } & $\mathrm{X}_{13}$ & 0,94 & Valid \\
\hline & $\mathrm{X}_{14}$ & 0,95 & Valid \\
\hline & $\mathrm{X}_{15}$ & 0,78 & Valid \\
\hline & $\mathrm{X} 16$ & 0,73 & Valid \\
\hline \multirow{4}{*}{ Industrial Environmental (IE) } & $\mathrm{X}_{17}$ & 0,94 & Valid \\
\hline & $\mathrm{X} 18$ & 0,92 & Valid \\
\hline & $\mathrm{X} 19$ & 0,80 & Valid \\
\hline & $\mathrm{X}_{20}$ & 0,80 & Valid \\
\hline \multirow{4}{*}{ Teaching Factory (TF) } & $\mathrm{X}_{21}$ & 0,93 & Valid \\
\hline & $\mathrm{X}_{22}$ & 0,85 & Valid \\
\hline & $\mathrm{X}_{23}$ & 0,89 & Valid \\
\hline & $\mathrm{X}_{24}$ & 0,99 & Valid \\
\hline \multirow{4}{*}{$\begin{array}{l}\text { Absorption of vocational High School } \\
\text { graduates (ALV) }\end{array}$} & $\mathrm{X}_{25}$ & 0,93 & Valid \\
\hline & $\mathrm{X}_{26}$ & 0,86 & Valid \\
\hline & $\mathrm{X}_{27}$ & 0,99 & Valid \\
\hline & $\mathrm{X}_{28}$ & 0,54 & Valid \\
\hline
\end{tabular}

Source: Study Influence factors on Absorption of Workers in SMK Graduates: Case Study, 2019

\subsubsection{Model Match Test}

Structural model analysis in SEM begins with testing the suitability of the overall model seen based on the Goodness-of-Fit Index (GFI) statistical indicators of the LISREL output (Hair et al, 2006). Overall summary of the critical values of the model fit test can be seen in the summary of Table 2. 
Table2. Model Match Test

\begin{tabular}{|l|c|c|c|}
\hline Size degree & Value & $\begin{array}{c}\text { Acceptable level of } \\
\text { compatibilty }\end{array}$ & Match level \\
\hline Goodness of Fit Indices (GFI) & 0.76 & GFI $\geq 0,9$ & Good Fit \\
\hline Root Mean Square Error of Approximation (RMSEA) & 0.068 & RMSEA $\leq$ o,o8 (good fit) & Good Fit \\
\hline Normed Fit Index (NFI) & 0.96 & NFI > o,90 & Good Fit \\
\hline Adjusted GFI (AGFI) & 0.68 & AGFI $\geq 0,90$ & Marginal Fit \\
\hline Comparative Fit Index (CFI) & 0.97 & CFI > o,90 & Good Fit \\
\hline Incremental Fit Index (IFI) & 0.97 & IFI > o,9o & Good Fit \\
\hline Relative Fit Index (RFI) & 0.95 & RFI > 0,90 & Good Fit \\
\hline
\end{tabular}

Source: Study Influence factors on Absorption of Workers in SMK Graduates: Case Study, 2019

The result of the model fit test is known that RMSEA is smaller than 0.08 so it is said to be a good fit model, the results of the GFI, NFI, CFI, IFI and RFI tests meet the suitability of the model by each getting a value greater than 0.90 indicating good fit data. Whereas the AGFI test results did not meet the level of model compatibility by obtaining values smaller than 0.90 .

\subsubsection{Structural Relationship}

The structural relationship between the exogenous latent variables and the endogenous latent variables that are the focus of this study is shown as follows.

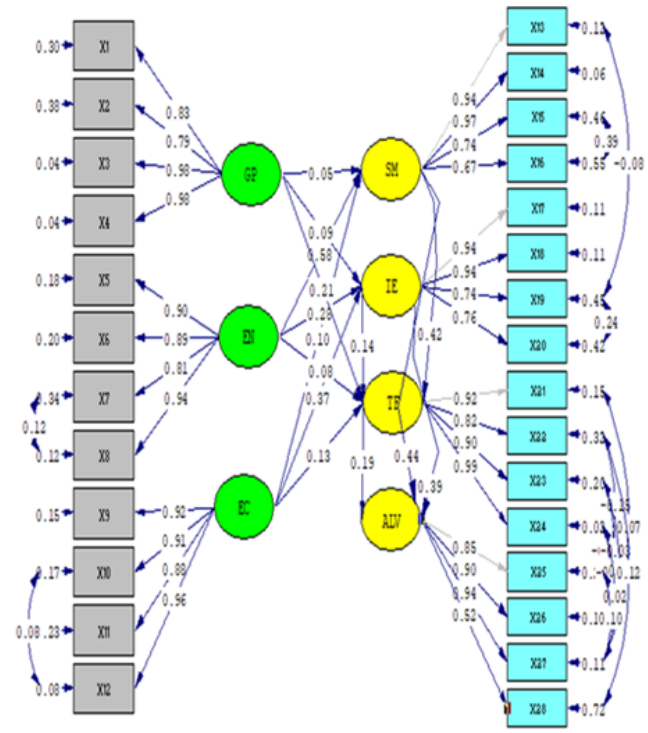

Chi-Sq̣are=888.86, df =212, p-ralue=0.006351, RUsen=0.068

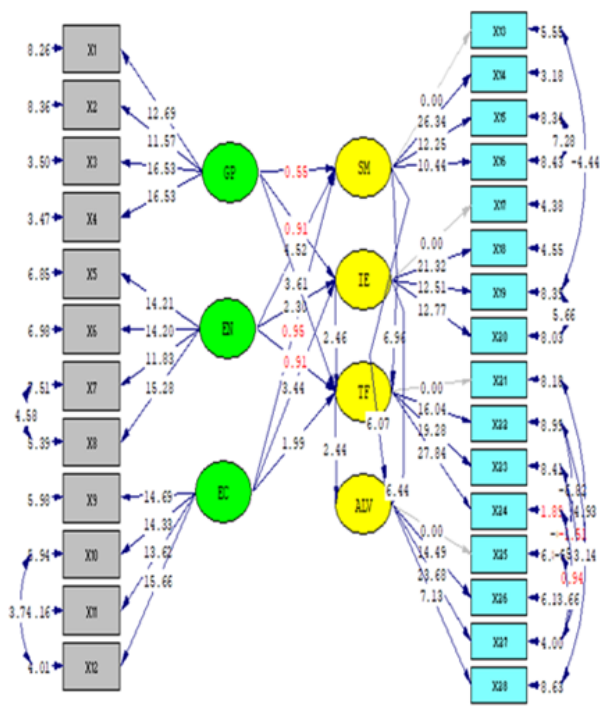

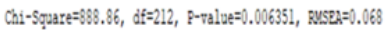

Diagram 2. Standart Solution

Diagram 3. T-Value

Diagram 2 \& 3: Structural relationship between the exogenous variables and the endogenous variabes Source: Study Influence factors on Absorption of Workers in SMK Graduates: Case Study, 2019. 


\subsubsection{Hypothesis testing}

Hypothesis testing in this study was done by looking at the critical value (CR) at a $95 \%$ confidence level or $5 \%$ error, then the CR value received was> 1.96 (Hair, et.al., 2006). The table 4 explains that the nine hypotheses proposed are acceptable because they obtain a t-value $>1.96$, while four rejected hypotheses have a t-value $<1.96$.

Table 3. Hypothesis Test Results

\begin{tabular}{|c|c|c|c|c|}
\hline No. & Hypothesis & Loading & T-Value & Conclusion \\
\hline 1 & $\begin{array}{l}\text { Government Policy (GP) on } \\
\text { School Management (SM) }\end{array}$ & 0,05 & 0,55 & Hypothesis rejected \\
\hline 2 & $\begin{array}{l}\text { Government Policy (GP) on the } \\
\text { Industrial Environmental (IE) }\end{array}$ & 0,09 & 0,91 & Hypothesis rejected \\
\hline 3 & $\begin{array}{l}\text { Government Policy (GP) on } \\
\text { Teaching Factory (TF) }\end{array}$ & 0,21 & 3,61 & Hypothesis accepted \\
\hline 4 & $\begin{array}{l}\text { Employment Needs (EN) on } \\
\text { School Management (SM) }\end{array}$ & 0,58 & 4,52 & Hypothesis accepted \\
\hline 5 & $\begin{array}{l}\text { Employment Needs (EN) on the } \\
\text { Industrial Environmental (IE) }\end{array}$ & 0,28 & 2,30 & Hypothesis accepted \\
\hline 6 & $\begin{array}{l}\text { Employment Needs (EN) on } \\
\text { Teaching Factory (TF) }\end{array}$ & 0,08 & 0,91 & Hypothesis rejected \\
\hline 7 & $\begin{array}{l}\text { Environmental Condition (EC) on } \\
\text { School Management (SM) }\end{array}$ & 0,10 & 0,95 & Hypothesis rejected \\
\hline 8 & $\begin{array}{l}\text { Environmental Condition (EC) on } \\
\text { Industrial Environmental (IE) }\end{array}$ & 0,37 & 3,44 & Hypothesis accepted \\
\hline 9 & $\begin{array}{l}\text { Environmental Condition (EC) } \\
\text { influences Teaching Factory (TF) }\end{array}$ & 0,13 & 1,99 & Hypothesis accepted \\
\hline 10 & $\begin{array}{l}\text { School Management (SM) on } \\
\text { Teaching Factory (TF) }\end{array}$ & 0,42 & 6,96 & Hypothesis accepted \\
\hline 11 & $\begin{array}{l}\text { Industrial Environmental (IE) on } \\
\text { Teaching Factory (TF) }\end{array}$ & 0,14 & 2,46 & Hypothesis accepted \\
\hline 12 & $\begin{array}{l}\text { School Management (SM) on Absorption of } \\
\text { vocational High School graduates (ALV) }\end{array}$ & 0,44 & 6,07 & Hypothesis accepted \\
\hline 13 & $\begin{array}{l}\text { Industrial Environmental (IE) on Absorption of } \\
\text { vocational High School graduates (ALV) }\end{array}$ & 0,39 & 6,44 & Hypothesis accepted \\
\hline 14 & $\begin{array}{l}\text { Teaching Factory (TF) on Absorption of } \\
\text { vocational High School graduates (ALV) }\end{array}$ & 0,19 & 2,44 & Hypothesis accepted \\
\hline
\end{tabular}

Source: Study Influence factors on Absorption of Workers in SMK Graduates: Case Study, 2019

\subsubsection{Testing indicators in variables}

Based on the results of structural testing it is known that the relationship between the indicators of the exogenous latent variable and the latent endogen variable. The goal is to look at the contribution of indicator values to each variable, as shown in table 4 . 
Table 4. Test results of relationships between indicators of exogenous latent variables and endogenous latent variables

\begin{tabular}{|c|c|c|c|c|}
\hline Variables & Indicators & $\begin{array}{l}\text { Loading } \\
\text { value }\end{array}$ & $\begin{array}{l}\text { Construct } \\
\text { Coefficient }\end{array}$ & Contribution \\
\hline $\begin{array}{l}\text { Government } \\
\text { Policy (GP) }\end{array}$ & $\begin{array}{l}\mathrm{x} 1=\text { Preparation of training modules } \\
\mathrm{x} 2=\text { Training funds } \\
\mathrm{x} 3=\text { Provision of instructors } \\
\mathrm{x} 4=\text { Practice facilities }\end{array}$ & $\begin{array}{l}0.30 \\
0.38 \\
0.04 \\
0.04\end{array}$ & $\begin{array}{l}0.83 \\
0.79 \\
0.98 \\
0.98\end{array}$ & $\begin{array}{l}0.2490 \\
0.3002 \\
0.0392 \\
0.0392\end{array}$ \\
\hline $\begin{array}{l}\text { Employment } \\
\text { Needs (EN) }\end{array}$ & $\begin{array}{l}\mathrm{x} 5=\text { Number of job opportunities } \\
\mathrm{x} 6=\text { Competence required } \\
\mathrm{x} 7=\text { Training resources } \\
\mathrm{x} 8=\text { job opportunity information }\end{array}$ & $\begin{array}{l}0.18 \\
0.20 \\
0.34 \\
0.12\end{array}$ & $\begin{array}{l}0.90 \\
0.89 \\
0.81 \\
0.94\end{array}$ & $\begin{array}{l}0.1620 \\
0.1780 \\
0.2754 \\
0.1128\end{array}$ \\
\hline $\begin{array}{l}\text { Environmental } \\
\text { Condition (EC) }\end{array}$ & $\begin{array}{l}\mathrm{x} 9=\text { Population development } \\
\mathrm{x} 10=\text { Natural resource potential } \\
\mathrm{x} 11=\text { Utilization of natural resources by DUDI } \\
\mathrm{x} 12 \text { = DUDI development }\end{array}$ & $\begin{array}{l}0.15 \\
0.17 \\
0.23 \\
0.08\end{array}$ & $\begin{array}{l}0.92 \\
0.91 \\
0.88 \\
0.96\end{array}$ & $\begin{array}{l}0.1380 \\
0.1547 \\
0.2024 \\
0.0768\end{array}$ \\
\hline $\begin{array}{l}\text { School } \\
\text { Management (SM) }\end{array}$ & $\begin{array}{l}\text { x13 = Study program management } \\
\text { x14 = Facility management } \\
\text { x15 = Learning management } \\
\text { x16 = Graduate distribution management }\end{array}$ & $\begin{array}{l}0.12 \\
0.06 \\
0.46 \\
0.55\end{array}$ & $\begin{array}{l}0.94 \\
0.97 \\
0.74 \\
0.67\end{array}$ & $\begin{array}{l}0.1128 \\
0.0582 \\
0.3404 \\
0.3685\end{array}$ \\
\hline $\begin{array}{l}\text { Industrial } \\
\text { Environmental (IE) }\end{array}$ & $\begin{array}{l}\mathrm{x} 17 \text { = Variations of DUDI } \\
\mathrm{x} 18=\text { Career advancement } \\
\mathrm{x} 19=\text { Type of business } \\
\mathrm{x} 20 \text { = Development of cooperation }\end{array}$ & $\begin{array}{l}0.11 \\
0.11 \\
0.45 \\
0.42\end{array}$ & $\begin{array}{l}0.94 \\
0.94 \\
0.74 \\
0.76\end{array}$ & $\begin{array}{l}0.1034 \\
0.1034 \\
0.3330 \\
0.3192\end{array}$ \\
\hline $\begin{array}{l}\text { Teaching } \\
\text { Factory (TF) }\end{array}$ & $\begin{array}{l}\text { X21 }=\text { Learning module } \\
\text { X22 }=\text { Competency requirements } \\
\text { x23 = Instructor competence } \\
\text { X24 = Learning facilities }\end{array}$ & $\begin{array}{l}0.15 \\
0.32 \\
0.20 \\
0.02\end{array}$ & $\begin{array}{l}0.92 \\
0.82 \\
0.90 \\
0.99\end{array}$ & $\begin{array}{l}0.1380 \\
0.2624 \\
0.1800 \\
0.0198\end{array}$ \\
\hline $\begin{array}{l}\text { Absorption of } \\
\text { vocational High } \\
\text { School graduates } \\
\text { (ALV) }\end{array}$ & $\begin{array}{l}\text { X25 }=\text { type of work } \\
\text { x26 = Career guarantee } \\
\text { x27 = Level of income } \\
\text { x28 = Permanent worker }\end{array}$ & $\begin{array}{l}0.10 \\
0.10 \\
0.11 \\
0.72\end{array}$ & $\begin{array}{l}0.85 \\
0.90 \\
0.94 \\
0.52\end{array}$ & $\begin{array}{l}0.0850 \\
0.0900 \\
0.1034 \\
0.3744\end{array}$ \\
\hline
\end{tabular}

Source: Study Influence factors on Absorption of Workers in SMK Graduates: Case Study, 2019

\section{Discussion}

Table 3 shows that government policy variables (GP) tend to have a negative influence on school management (SM) and industrial environment (IE). The hypothesis of the relationship between GP with SM and IE was declared rejected, because $<1.96$. Perhaps this is due to the government's lack of participation in schools and industry in issuing the Tefa policies. Particularly from the industrial side, government policies are considered to be non-binding and are often merely appeals without the ability to involve their participation. From interviews in the field it was found that quite a lot of DUDI were less willing to be involved in the administration of education in vocational high schools. However, government policies have a positive influence on the implementation of the Tefa program in SMK which are often accompanied by operational funding assistance and certain facilities.

Data analysis also shows that the employment needs (EN) variable has the biggest positive effect on the school management variable (SM) compared to the industrial environment (IE) and even negatively on the Tefa variable (TF). This means that the work needs around are indeed responded and received serious attention in school management, as well as the creation of work in the industrial environment (IE), but it is still less related to the implementation of the Tefa (TF) program. The Tefa Program is more of a gift by the government and schools merely accepting, without linking or aligning with the needs of the workforce around. In addition, the industrial 
environment (IE) still lacks commitment and participates in implementing Tefa (TF) in schools. Indriaturrahmi and Sudiyatno (2016), Wibowo (2016), and Ixtiarto and Sutrisno (2016) studies, for example, tend to show an inadequate relationship between SMK and the industrial environment and the implementation of the Tefa program.

Variable environmental conditions (EC) do not have a positive effect on school management (SM). The proposed hypothesis was declared rejected, meaning that the management of vocational education programs implemented by SMKs paid less attention to the physical and social potential around them. Field observations not infrequently show the implementation of vocational education is less appropriate and not even associated with efforts to develop and exploit environmental potential. Irfan, Nurlaela, and Sunardi (without years) stated that the reality was that vocational schools were still not promising, among others the irrelevance of competencies possessed by graduates with existing regional superior potential. Aini, Tarigan, and Rujiman said that the development of vocational schools is currently still based on public interest in majors considered to be a trend, especially to find work in urban areas in the formal sector. Regional development has been slow because SMKs have not implemented educational programs that pay attention to their environmental potential. On the other hand environmental conditions (EC) have a positive influence on the industrial environment (IE), but in limited variations. This can be understood because the industrial environment around SMK that are studied is more reliant on the use of natural resources as raw material for production in the company. Table 3 shows that the EC, SM, and IE variables have a positive influence on the implementation of the Tefa program in SMK.

Table 3 also shows that School Management (SM), Industrial Environmental (IE), and Tefa program variables have a positive effect on the Absorption of vocational High School (ALV) variable. What's interesting about this effect is the number of directional coefficients of the SM and IE variables that are greater than the Tefa variable itself against the ALV variable. This can be interpreted that the Tefa program carries less meaning for the absorption of graduates, but rather is based on school backgrounds and industry needs. In field observations it was found that the Tefa program in SMKs was not running effectively and was unable to produce graduates who could be absorbed into the world of work. Fathurrohman (2016) suggests that Tefa learning is often not optimal because it is hampered by inappropriate implementation time, limited infrastructure, user mistrust, and the required worker competencies cannot be fulfilled through the implementation of the Tefa program.

On the other hand, table 4 shows that the training funding assistance indicator ( $\mathrm{x} 2$ ) contributed the highest by 0.3002 to the government polici variable (GP), followed by the training module preparation indicator $\left(\mathrm{x}_{1}\right)$ of 0.2490 , and the provision of Instructors $\left(\mathrm{x}_{3}\right)$ and practice facilities $\left(\mathrm{x}_{3}\right)$ $\mathrm{x} 4$ ) amounting to 0.0392 . The results of interviews with school principals and vocational students found that they needed funding assistance and training modules more than providing instructors and practice facilities. With financial assistance students can take practical training in a designated company or provide an expert fee from the university rather than being trained by instructors who are often less competent. The availability of funds can be used to support students seeking practical skills elsewhere that are suitable to industry needs. Yudithia (2014) found that there is an influence of school education funding on vocational student competencies in productive subject groups of expertise programs. Setyawati (2018) also found that providing financial assistance through the Indonesia Smart Card program had a significant influence on the formation of the skills of the vocational students studied.

In the Environment Needs variable (EN) the highest contributing indicator is training resources (x7) of 0.2754 , followed by competency requirements (x6) of 0.1780 , number of job opportunities ( $x_{5}$ ) of 0.1620 , and information job opportunities (x8) amounted to 0.1128 . These results indicate that the availability of training resources is very important in the EN variable, especially its function as a supplier of workers needed by the company. DUDI in particular, prefers to accept workers who have undergone training from trusted institutions, because vocational graduates are often considered not yet competent and still need additional work skills. Although SMK graduates have gone through the 
Tefa program it is still considered inadequate and meets the criteria for recruitment into available employment opportunities.

In the variable Environmental Condition (EC) indicators that gave the highest contribution were the utilization of natural resources by DUDI (xil) of 0.2024 , followed by natural resource potential (x10) of 0.1547 , population development (x9) of 0.1380 , and DUDI development $\mathrm{X}_{12}$ ) of o.0768. Students think that DUDI's use of natural resources and other environmental potentials are important aspects of creating employment opportunities and giving priority to local workforce, not from other regions. The growth in the number and variety of DUDI utilizing natural resources and other business activities that accompany it is not a problem for students from school, but it is hoped that schools can anticipate and respond to existing needs. DUDI is also expected to be more informative and communicative towards schools regarding work opportunities and required competencies. Pramono (2009) suggested that although industrial activities still use traditional technology in exploiting environmental potential, they are able to absorb the local workforce of SMK graduates. On the other hand Wibowo (2016) found that Vocational High Schools (SMK) were often not able to prepare competent workforce and had not been intensively collaborating with DUDI.

Indicators graduate distribution management (x16) was the highest contribution to the school management (SM) variable of 0.3685 , followed by the learning management indicator (x15) of 0.3404 , study program management (x13) of 0.1128 , and facility management (x14) of 0.0582 . These results indicate that students prioritize schools to be able to manage and distribute their graduates to DUDI, so that education is truly considered beneficial by them. Schools are expected to foster cooperation with DUDI, especially in distributing graduates to work. Another important aspect is the management of learning in schools in developing competencies according to the needs of the workforce. Hidayati (2015) one of which shows the relationship of school collaboration with DUDI not only supports employment but also the possibility to create a Joint curriculum between schools, DUDI, and the local government. In line with that, Indriaturrahmi and Sudiyatno (2016) suggested that school collaboration with DUDi could be related to the implementation of work practices in industry, teacher apprenticeship places, places to deliver graduates, and curriculum development. In collaboration with SMK and DUDI, it is necessary to develop suitable study programs and use of practical facilities in industry.

The highest contribution to environmental industry variables (IE) was the type of business indicator (x19) of 0.3330 , followed by the cooperation development indicator (x20) of 0.3192 , variations of DUDI (x17) and career enhancers (x18) of 0.1034 . These results indicate that students in particular perceive the relevance of the DUDI type of business as the main aspect in the implementation of education in schools, so that they can absorb graduates. The second aspect is the importance of promoting cooperation between schools and DUDI, both in terms of developing curriculum of learning, training, internships, and others. Khadir, Nirwansyah, and Bachrul (2016) suggested that the implementation of vocational education in Indonesia generally still faces problems of inter-institutional coordination that is less conducive, especially between local governments, schools, and DUDI. In terms of the number and variety of DUDI are considered the lowest aspects, because even though they are few in number, they can absorb vocational graduates into employment opportunities. The same thing refers to the opinion that DUDI is more expected to be able to recruit vocational graduates as workers, rather than questioning a work career. The latter suggests that SMK graduates are more anxious if they are not absorbed into the world of work, while on the other hand they still don't care about the aspects of improving work careers.

What about the Tefa program? In the teaching factory (TF) indicator which gave the highest contribution were competency requirements (x22) of 0.2624 , followed by instructor competence indicator (x23) of 0.1800 , learning module (x21) of 0.1380 , and learning facilities (x24) of 0.0198 . This means that in implementing the Tefa program it is hoped that schools will be able to provide learning in accordance with the competencies needed by DUDI. Schools should work together with DUDI, Experts, or Practitioners to be able to provide competent instructors. Khadir, Nirwansyah, and Bachrul (2016) suggested that the Tefa program in Indonesia combines Competency Based Training 
(CBT) and Production Based Training (PBT) based still faces a shortage of teachers / instructors in terms of quantity and quality. As a result, SMK tend to produce graduates with low skills and are considered not to meet the competencies of workers desired by DUDI. It is not surprising if the statistical figures record high unemployment of SMK graduates, one of the reasons is the inability of SMK to meet the work requirements required by DUDI. The sequence above fulfills the logic of thinking that the DUDI expectation requires a Tefa program supported by competent instructors, learning modules, and adequate learning facilities.

From the student side, the indicator of permanent workers (x28) provides the highest contribution to the absorption variable of vocational high school graduates (ALV), followed by income levels (x27) 0.1034, career guarantees (x26) 0.0900, and type of work (x25) in the amount of 0.0850 . These results indicate that students prioritize being accepted as permanent workers, not by contractual agreements for one or two years. The level of income is not a problem, as long as it complies with company regulations. Vocational school graduates also tend not to question the type of work to be done or demand career guarantees. Since the beginning, most students choose vocational schools because they want to work, without questioning whether the school and study program chosen is suitable and needed by the business world. In fact, many students do not understand the application of Tefa in carrying out their education. According to students, many SMK graduates are not absorbed in the workforce, not because of excess supply compared to demand but because schools are less able to develop graduate competencies to fill employment opportunities in DUDI. In line with that Putranto (2017) argues, it is necessary to develop cooperation between schools and DUDI to improve student work readiness through involvement and suitability of student competencies needed by DUDI. A study by Dewi (2017) also found low DUDI participation in SMK, a mismatch of competencies learned by students, and a low competency of graduates produced by SMK.

\section{Conclusion}

This study found that the exogenous latent variables of government policy (GP), the needs or job opportunities around (EN), and the potential environmental conditions (EC) which have a positive or vice versa effect on the latent variables endogenous school management (SM), industrial environment (IE) and teaching factory (TF). Another finding is that the SM and (IE) variables have a positive effect on the teaching factory (TF) variable and the three (SM, IE, and TF) have a positive effect on the absorption of vocational High School graduates (ALV) variables.

The interesting thing is that the variables of school management (SM) and environmental industry (IE) have a greater positive influence than the Tefa program on the variable absorption of vocational High School graduates (ALV). This means that the implementation of the Tefa (TF) program is still insignificant in absorbing vocational school graduates, because it is more directed towards developing low skills. On the contrary, it has not been able to meet the needs of mid and high level competencies of DUDI. In the hotel business, for example, graduates of Hospitality Vocational Schools tend to supply low-skilled workers (to be cleaning services, receptions, servants, etc.), on the contrary it is still difficult to recruit skilled graduates as managers, marketing, and others. Yet this competency is needed by DUDI and is considered to be a determinant of business continuity.

On that basis several things are recommended for the implementation of vocational education in vocational schools, namely: government policies that give authority to vocational schools to develop education in accordance with the conditions of the potential environment, increase cooperation between local schools - and DUDI, enhance Tefa learning which does not only refer to Low skill development, but more directed to meet competencies according to the needs of the workforce by developing curriculum and shared work practices. Without the synergy between the government, DUDI and Vocational School, vocational education as an effort to develop quality, competitive, and ready-to-use human resources will lead to less success. 


\section{References}

Aini, N., Tarigan, R., Rujiman. (2013). The Attraction Analysis of Determination of Vocational Location Based on Regional Development in Simalungun Regency, Journal of Economi, Vol. 16 (3), 132 - 145. http://repository.usu.ac.id/bitstream/handle/123456789/43535/nurainirobinsonrujiman. pdf.

Aini, Q., Sulistyarso, H., Purwadio, H. (no year), Concept of Development of Industrial-Based Vocational Schools (SMK) in Sidoarjo Regency, Journal of Spatial Planning. https://docplayer.info/30842745-Konseppengembangan-sekolah-menengah-kejuruan-smk-berbasis-industri-di-kabupaten-sidoarjo.html.

Andreas, D. (2018). Why are the Most Unemployed? Instead of SMK Graduates?. https://tirto.id/mengapapengangguran-terbanyak-justru-lulusan-smk-cJ6Y.

Anwar, N., A.G. Wailanduw. (2018). Implementation Evaluation and Inhibiting Factors and Teaching Factory Supporters at SMK Negeri 3 Surabaya, JPTM. Vol. o7 (o1), 94-101.

Arifman, R. N. (2017). Teaching Factory Implementation in SMKN 1 Magelang Light Vehicle Engineering Expertise Program, Automotive Engineering Study Program, Faculty of Engineering, Yogyakarta State University.

Asmani, J.M. (2012). Local Excellence Based Education. Jogjakarta: Diva Press.

Cahyanti, S. D., Indriayu, M., Sudarno. (2018). Implementation of Link and Match Program with the Business World and the Industrial World in Marketing Graduates of SMK Negeri 1 Surakarta, BISE: Journal of Business and Economic Education, Vol. 4 (1). DOI: http://dx.doi.org/10 .20961/bise.v4i1.20 028.

Central Bureau of Statistics. (2016). Employment Data. Jakarta.

Central Bureau of Statistics. (2017). Employment Data. Jakarta.

Central Bureau of Statistics. (2018). Employment Data. Jakarta.

Coordinator for the Economy of the Republic of Indonesia. (2017). Vocational Development Policy Road Map in Indonesia, Jakarta.

Dardiri, A. (2015). Optimizing Collaboration in Industrial Work Practices to Improve School Image and Competitiveness of Vocational School Graduates, Journal of Education and Learning, Vol. 22 (2), 162 - 168. http://journal.um.ac.id/index.php/pendidikan-dan-pembelajaran/article/ view/7742/3561.

Dewi, A. (2017). Management of Industrial Work Practices Program in Accounting Skills Competency at SMK N 2 Pekalongan, Thesis, Semarang State University. https://lib.unnes.ac.id/3079o/ 1/7101413404.pdf

Directorate of Vocational Education. (2015). Grand Design Teaching Factory and Technopark Development at SMK, Director General of Primary and Secondary Education - Ministry of Education and Culture of the Republic of Indonesia.

Directorate of Vocational Education. (2017a). A Guide to Synchronizing the Fields of Expertise in Vocational Schools with Priority to Regional Potential and Workforce Priorities, Director General of Primary and Secondary Education - Ministry of Education and Culture of the Republic of Indonesia.

Directorate of Vocational Education. (2017b). Teaching Factory Management, Director General of Primary and Secondary Education - Ministry of Education and Culture of the Republic of Indonesia.

Directorate of Vocational Education. (2018a). Regulation of Power of Attorney User Budget Work Unit Directorate of Vocational High School Development Number: 082 / D5.3 / KU / 2018 concerning Guidelines for Implementing Government Teaching Factory Assistance in 2018.

Directorate of Vocational Education. (2018b). Regulation of Power of Attorney User Budget Work Unit Directorate of Vocational High School Development Number: 083 / D5.3 / KU / 2018 concerning Guidelines for Implementing Government Assistance in 2018 Technopark.

Disas, E.P. (2018). Link and Match as Vocational Education Policy, Educational Research Journal, Vol. 18 (2), 231 242.http://ejournal.upi.edu/index.php/ JER/article/view/ 12965

Djojonegoro, W. (1999). Human Resource Development: Through Vocational High Schools (SMK). Jakarta: Balai Pustaka Publisher.

Haryono, S., Wardoyo, P. (2017). Structural Equation Modeling (SEM) for Management Research with AMOS 18.oo, Jakarta: Luxima Metro Media.

Fajaryati, N. (2012). Evaluation of Vocational Teaching Factory Implementation in Surakarta, Journal of Vocational Education, Vol 2 (3), $325-337$.

Fathurrohman, W. (2016). Teaching Factory (Tefa) Implementation in Technology and Engineering Expertise Program at SMK Negeri 4 Semarang, Thesis, Faculty of Engineering, Semarang State University. https://lib.unnes.ac.id/27476/1/5201409029. pdf

Hair Jr. J. F., William C., Black Ba. J., Babin R. E. A. (2010). Multivariate Data Analysis, United States: Pearson

Handayani, T. (2015). The Relevance of Indonesian University Graduates with the Need for Workers in the Global Era, Indonesian Population Journal, Vol. 10 (1), 53-64. https://www.researchgate.net/publication/319571232 _relevansi_lulusan_perguruan_tinggi_di_indonesia_dengan_kebutuhan_tenaga_kerja_di_era_global. 
Handayani, K., Mundilarno., Mariah, S. (2018). Teaching Factory Management Implementation in Leather Craft Study Program at SMKN 1 Kalasan, Educational Management Media. Vol. 1 (1), 122- 136.

Haris, A. (2013). Teaching Factory as an Educational System Development in Vocational High Schools, Business Tips, Vol. 5 (3), 167 - 178. http://journal.unwidha.ac.id/ index.php /KIATBISNIS/article/viewFile/1039/194

Hidayati, A. (2015). Relevance of Competence of Vocational High School Graduates to the Needs of Business and Industry, Surakarta Muhammadiyah University. http://eprints.ums.ac.id/ 32973/13/NASKAHPUBLIKASI.pdf

Husen, K. (200o). Analysis of Tourism Workforce Needs, Journal of Tourism Science, Vol. 4 (3), 26 - 40. https://www.researchgate.net/publication/282332962_Analisis_Kebutuhan_Tenaga_Kerja_Pariwisata/link /56oce8e708aed543358d53ob/download.

Indriaturrahmi., Sudiyatno. (2016). The Role of Business and Industry in the Implementation of Local WisdomBased Vocational Schools, Journal of Vocational Education, Vol. $6 \quad(2)$, $162-172$. http://journal.uny.ac.id/index.php/jpv.

Irfan, A. M., Nurlaela, Sunardi. (without years). Vocational School Based on Regional Potential and Community Needs as an Effort to Eliminate the Image of Second Choice Schools, National Seminar of the Faculty of Engineering, Makassar State University, 409 - 415. http://eprints.unm.ac.id/580o/63/59\%20Andi\%2oMuhammad\%2oIrfan.pdf.

Ixtiarto, B., Sutrisno, N. (2016). Partnership of Vocational High Schools With the Business and Industrial World (Study of Management aspects at SMK Muhammadiyah 2 Wuryantoro Wonogiri Regency), Journal of Social Sciences Education, Vol. 26 (1), 57 - 69.

Judisseno, Rimsky K. (2008). Be Competent Person at Work, Jakarta: Gramedia Pustaka Utama.

Khadir, S., Nirwansyah, Bachrul, B. A. (2016). Technical and Vocational Education and Training in Indonesia: Challenges and Opportunities for the Future, Singapore: The Lee Kuan Yew School of Public Policy.

Kusnendi, (2008). Structural Equation Models, Bandung: Alfabeta.

Kuswantoro, A., Widodo, J., Kuswardinah, A. (2012). Teaching Factory Planning In an Effort to Embed Entrepreneurship Values at SMK Negeri 6 Semarang, Journal of Educational Research and Evaluation, Vol. 1 (2), 93 - 100. https://journal.unnes.ac.id/sju/ index.php/jere.

Okezone. (2019). Industrial Workforce Needs Predicted to Increase by 8\%. https://economy. okezone.com/read/2019/05/07/320/2052509/kebutuhan-tenaga-kerja-industri-diprediksi-naik-8.

Republic of Indonesia Government Regulation Number 29 Year 1990

Perdana, N. S. (2018). Evaluation of the Implementation of Teaching Factory Learning Model in an Effort to Improve the Quality of Graduates, Journal of Educational Administration Literature, Vol.7 (1), 43 - 57.

Perdana, N. S. (2019). Optimizing the Labor Market Balance of Vocational School Graduates, Educatic Reflections: Educational Scientific Journal, Vol. 9 (2), 172-181. https://jurnal. umk.ac.id /index.php/RE.

Pramono, Y. (2009). Study of Needs and Provision of Vocational High Schools in Rembang Regency, Thesis, Postgraduate Program in Urban and Regional Development Engineering at Diponegoro University, Semarang. https://core.ac.uk/download/pdf/ 11719605.pdf

Priyono. (2016). Introduction to Management. Jakarta: Zifatama Publisher.

Purnanto, N. E., Imron, A. (2012). Management Development Cooperation between Schools and Businesses in Efforts to Improve Education Quality, Journal of Education Management, Vol. 23 (5), 439 - 444. https://www.academia.edu/35860552/Jurnal_Manajemen_Pendidikan_Volume_23_no.5.

Putranto, I. (2017). Pengembangan Model Kerja Sama Link and Match Untuk Meningkatkan Kesiapan Kerja Bagi Lulusan SMK Kompetensi Keahlian Akuntansi di Kota Semarang, Jurnal Mandiri: Ilmu Pengetahuan, Seni, dan Teknologi, Vol. 1 (1), 69 - 83. file:///10-ArticleText-20-1-10-20170811.pdf

Manullang, L. A. (2013). Management Theory: Comprehensive - Integralistic. Jakarta: Salemba Empat.

Mustari, Sudana, I. M., Supraptono, E. (2017). Teaching Factory Model for Learning Planning and Installing Audio Systems, Journal of Vocational and Career Educational, Vol. 2 (2), 96-105. https://journal.unnes.ac.id/sju/index.php/jvce.

News Detik. (2017). Minister of Manpower: RI Needs 3.7 Million Skilled Workers Per Year. https://news.detik.com/berita/d-3474059/menaker-ri-butuh-37-juta-tenaga-kerja-terampil-per-tahun.

Nurdin. (2011). Effective and Excellent School Management, Journal of Educational Administration, Vol. 13 (1), 1 8. http://ejournal.upi.edu/index.php/JAPSPs/ article/view/6387/4344.

Raharjo, S. B., Yuliana, Y. (2016). School Management to Achieve Best and Fun School: A Case Study at a Senior Secondary School in Yogyakarta, Journal of Education and Culture, Vol. 1 (2), 203 - 217. https://jurnaldikbud.kemdikbud.go.id

Santosa, H. (2018). Teaching Factory Based Management of Boutique Clothing Competency Program in SMK Muhammadiyah Susukan Semarang Regency, Thesis, Muhammadiyah University, Surakarta. http://eprints.ums.ac.id/67201/1/11.NASKAHPUBLIKASI.pdf. 
Sari, R. M. (2017). Application of Teaching Factory Learning Model to Improve Body Repair and Body Body Skills Competency in Vocational High School, Thesis, Automotive Engineering Education Department of Mechanical Engineering, Faculty of Engineering - Semarang State University.

Setyawati, S. (2018). The Effectiveness of the Smart Indonesia Card Program (KIP) for Vocational Students in Jeruklegi District, Cilacap Regency (Permendikbud Study No. 12 of 2015 About the Smart Indonesia Program), Thesis, Purwokerto State Islamic Institute file:///F:/jurnalpublish/sarassetyawati_efektivitasprogramkartuindonesiapintar(kip)bagisiswasmkdikecamat anjeruklegikabupatencilacap.pdf

Siswanto, I. (2015). Teaching Factory Vocational Automotive Engineering Skills Program, Proceedings of the UMP Automotive Engineering National Seminar, May 23. https://docplayer.info/46330159-Teaching-factory-smkprogram-keahlian-teknik-otomotif-oleh-ibnu-siswanto.html.

Stoner, J. F. A. (2013). Introduction to Management, Yogyakarta: Graha Ilmu.

Sumantri, D., Subijanto, Siswantari, Sudiono, Warsana. (2016). Vocational Education Management Study: Development of a 4 Year Vocational School, Research Report, Research Center for Education and Culture Policy - MOEC Republic of Indonesia.

Terry, G. R. (2010). Principles of Management, University of California.

Traymansah, D. H., Soejitno, dan Pribadi, S. R. W. (2012). Analysis of Skilled Manpower Needs to Support Increased Production of New Shipbuilding in Shipyards in Surabaya, ITS Engineering Journal, Vol. 1 (1), 331 335. https://media.neliti.com/media/publications/146012-ID-analisa-kebutuhan-tenaga-kerja-terampil.pdf.

Law of the Republic of Indonesia Number 22 of 1999 concerning Local Government Systems.

Law of the Republic of Indonesia Number 32 of 2004 concerning Local Government Systems.

Law of the Republic of Indonesia Number 20 of 2003 concerning the National Education System.

Wagiran. (2010). Development of vocational education based on regional potential and natural resources in supporting continuing vocational education. Paper presented at Aptekindo Seminar at Denpasar University of Education, 29 April - 2 Mei.

Wati, L. F. (2018). Project Based Learning Model Based on Local Potential in Workshop and Entrepreneurship Subjects (SMA / SMK in Malang), JTP2IPS, Vol. 3 (1), 39 - 47. DOI: 10.17977/umo22v3i12018po39.

Wibowo, N. (2016). Efforts to Minimize Competency Gaps Competency Graduates of Vocational High Schools with Industrial Demands, Journal of Technology and Vocational Education, Vol. 23 (1), 45 - 50. https://media.neliti.com/media/publications/163789-ID-upaya-memperkecil-kesenjang an-kompetensi.pdf

Wijaya, M. B. R. (2013). Vocational High School Teaching Factory Management Model, Educational Research journal, Vol. 30 (2), 125 - 129. https://docplayer.info/29935036-Model-pengelolaan-teaching-factory-sekolahmenengah-kejuruan.html.

Yudithia. (2014). The Influence of School Education Funding Against Class XII Student Competencies in the Productive Subjects Group of Electric Power Engineering (TITL) Expertise Programs at SMK 1 Sedayu, Thesis, Faculty of Engineering, Yogyakarta State University. https://eprints.uny. ac.id/ 20783/1/Yudithiao8501244025.pdf

Yunanto, D. (2016). Teaching Factory Implementation in SMK 2 Gedangsari Gunungkidul, Vidya Karya Journal, Vol. 31 (1), 29 - 36. https://ppjp.ulm.ac.id/journal/ index.php/JVK/article/viewFile/ 3971/3564

Zainudin, I. (2012). The Contribution of Teaching Factory Implementation in Preparing Graduates for Entering the Work World of State Vocational School Students 5 Surakarta Academic Year 2011/2012. Sebelas Maret University. https://digilib.uns.ac.id 